\title{
Are you really a Sanctuary City?
}

\author{
Julian Agyeman ${ }^{1} \cdot$ Alexandra Duprey $^{1}$
}

Accepted: 24 April 2020 / Published online: 13 May 2020

(c) Springer Nature B.V. 2020

In The Immigrant-Food Nexus: Borders Labor and Identity in North America (MIT Press, 2020) Agyeman and Giacalone argue that food serves as an umbilical link between immigrants' new lives, and the lives they left behind. Food therefore acts a constant cultural reference point, an anchor in immigrant lives. To sustain and increase their wellbeing, immigrant foodways - the intimate daily performances of culture, community, and individual bodies - must be protected and enhanced, not only by well-meaning non-profits, but through city and municipal policy and planning.

Sanctuary Cities are those who have agreed to protect undocumented immigrants from deportation or prosecution, in light of federal immigration law. These cities, like Seattle, New Orleans, Boston, and New York City, have been hit particularly hard by the COVID-19 pandemic. The unprecedented hardships being faced by undocumented immigrants are compounded by their enforced invisibility and pre-existing inequalities that have only sharpened because of the pandemic. Their positions in multiple labor sectors are often insecure with lack of benefits and constraints in unionizing. This precarity has only worsened.

Immigrant communities are generally facing compounding trauma during the COVID-19 pandemic such as: language barriers and distance from family that exacerbate miscommunication about the virus and feelings of isolation, precarious housing arrangements that may deteriorate further during the crisis, greater risk of infection due to many working in the so-called service sector, fear and anxiety in seeking healthcare due to immigration status, and possible ineligibility for government benefits to alleviate their burden, like unemployment, sick leave, and the $\$ 1,200$ stimulus checks.

This article is part of the TopicalCollection: Agriculture, Food \& Covid-19.

Julian Agyeman

Julian.Agyeman@tufts.edu

1 Urban and Environmental Policy and Planning, Tufts University, Medford, USA
It is therefore imperative for Sanctuary Cities to act proactively, rather than in a reactive manner, to prevent further harm to immigrant and undocumented populations during the current crisis and beyond. But how can a Sanctuary City be proactive, acting more like a true "sanctuary"?

Sanctuary City politicians, administrators and urban planners and policymakers could prioritize city-owned land for immigrants to use for food generation. These spaces can become places of collective healing and regeneration after COVID-19. Many incoming immigrants may come from rural areas and have a strong knowledge of agricultural practices that could benefit community gardens. Immigrants could share new varieties of foods, methods of growing, and these areas could become spaces of engagement and contact between immigrant and settled communities. This could generate a platform for cross-cultural exchange and learning for the city. The gardens could become additional places for immigrants to exercise ideas and build agency, breaking the walls of isolation.

Community gardens oriented towards immigrant communities are already popping up across the country, including in Sanctuary Cities. The Welcome Project's Mystic Community Garden in Somerville, MA is run by a steering committee that oversees the garden and designates plots and community tasks. The Hillside Paradise Parking Plots garden in the Seattle area is an initiative that has repurposed an unused parking lot into a haven for vegetables from around the world, grown through the efforts of settled immigrants and refugees. In Queens, the New Roots Gardens initiative led by the cooperative effort of the International Rescue Committee (IRC) and New York City agencies aims to construct a community garden for refugees, asylees, and other immigrant populations. To do this, the city is reclaiming an old bridge structure, revitalizing it for the benefit of its high foreign-born population.

Beyond gardens, there are organizations like Sanctuary Kitchen, a program of CitySeed, which was formed in 2017 to promote and celebrate the culinary traditions, cultures, and stories of refugees resettled in New Haven and Connecticut and the Restaurant Opportunities Center United 
(ROCU) that prioritize immigrants in policies surrounding the restaurant industry, advocating for their rights, fair payment, and protections in the United States.

In imagining a healthy, thriving city beyond COVID-19, city officials must reconsider the valuable spaces they have dedicated to empty parking lots, abandoned plots, or otherwise underutilized structures. Transforming these spaces into places of both existential and physical growth will not only show immigrant communities that they are valued but will also provide opportunity for a true sanctuary to form, while generating conversations on how to support immigrants in other ways as well.

We cannot talk about immigration without talking about food, and vice-versa. As an avenue for stories and emotional intimacy, food can be healing in itself and a form of "radical self-care."
Sanctuary Cities must ask themselves how they can support and enhance the experience of undocumented peoples now, through our slow recovery from the COVID-19 crisis.

Publisher's Note Springer Nature remains neutral with regard to jurisdictional claims in published maps and institutional affiliations.

Julian Agyeman is a Professor of Urban and Environmental Policy and Planning at Tufts University.

Alexandra Duprey is a Master's student in Urban and Environmental Policy and Planning at Tufts University. 